\title{
PEJZAŻ JĘZYKOWY JAKO NOŚNIK DZIEDZICTWA KULTUROWEGO, NA PRZYKŁADZIE MIASTA POZNANIA
}

\author{
MARTA KOSZKO
}

\begin{abstract}
Wstęp
Niniejszy artykuł podejmuje dyskusję na temat alternatywnych form poznawania dziedzictwa kulturowego w przestrzeni miejskiej i zwraca uwagę na rolę, jaką pełnić może w tej aktywności pejzaż językowy. Przyjęto, że pejzaż językowy może być bogatym źródłem informacji na temat dziedzictwa kulturowego. Zarys teoretyczny nawiązuje do takich terminów jak przestrzeń, pejzaż językowy, nazewnictwo miejskie czy ekoturystyka i poprzedza analizę treści tablic informacyjnych, które są umiejscowione w przestrzeni miejskiej miasta Poznania i mogą służyć za nośnik informacji o dziedzictwie kulturowym.
\end{abstract}

\section{Przestrzeń}

Przestrzeń miejska jest źródłem niekończących się inspiracji dla badaczy z różnych dziedzin nauki i życia. Dyskusje dotyczące zjawisk i procesów zachodzących w aglomeracjach miejskich i są obecnie dość powszechne, a każda $\mathrm{z}$ prowadzonych debat sprawia, że przestrzeń staje się nam, jej użytkownikom coraz bliższa, ciekawsza, znajoma. Nie jest już jedynie szarą masą wytworów architektonicznych, staje się sztuką, dialogiem, komunikatem, każdy zaczyna odczuwać potrzebę jej odkrywania. Proces poznawania przestrzeni miejskiej, pragnienie odczytywania $\mathrm{w}$ niej wielorakich komunikatów wydaje się naturalnym zachowaniem użytkownika przestrzeni. Co poznane i zbadane zdaje się być 
bardziej czytelne i zrozumiałe. Przestrzeń i człowiek są nierozłączne i od siebie zależne. Jedno kreuje drugie, nadając mu kształt, umożliwiając egzystencję. Skoro człowiek jest twórcą przestrzeni, ma ona naturalnie charakter społeczny, co więcej można śmiało stwierdzić, że jest nośnikiem znaczeń, mowy, języka i wszelakich historii językiem przestrzeni opowiedzianych. Pojęciem, które można uznać za łącznik pomiędzy przestrzenią, językiem, którym się posługuje i jej czytelnikami jest pejzaż językowy (ang. linguistic landscape patrz. Landry i Bourhis 1997).

\section{Pejzaż językowy (ang. linguistic landscape) i nazewnictwo}

\subsection{Pejzaż językowy}

'Pejzaż językowy' wtopiony w przestrzeń miejską staje się przedmiotem coraz większego zainteresowania wśród polskich językoznawców czy socjologów. Definicja 'pejzażu językowego' (ang. linguistic landscape, Landry i Bourhis 1997) nawiązuje do tekstów umieszczanych na różnego rodzaju znakach, tj. znakach drogowych, na tablicach z nazwami ulic, na tablicach informacyjnych, billboardach reklamowych, znakach publicznych na instytucjach rządowych itd. Informacje zawarte na znakach, szczególnie tych wytworzonych przez osoby prywatne, mogą dostarczyć wielu istotnych informacji na temat miejsca, w którym zostały umieszczone, ludzi, którzy żyją w obrębie danego terytorium oraz o relacjach społecznych panujących na danym obszarze. Tablice informacyjne, przeanalizowane $\mathrm{i}$ omówione $\mathrm{w}$ niniejszym artykule, również wpisują się $\mathrm{w}$ pejzaż językowy przestrzeni miejskiej.

\subsection{Funkcja informacyjna i mitologiczno-folklorystyczna pejzażu językowego}

Pejzaż językowy spełnia kilka istotnych funkcji, których znaczenie może różnić się w zależności od miejsca, w którym elementy pejzażu występują. Dotychczas mówiło się o trzech głównych funkcjach, symbolicznej, informacyjnej (Landry i Bourhis 1997) oraz o mitologiczno folklorystycznej (Hicks 2002). W kontekście dziedzictwa kulturowego i przestrzeni miejskiej, istotna wydaje się być funkcja mitologiczno-folklorystyczna. Pozostałe dwie są szeroko brane pod uwagę $\mathrm{w}$ dyskusjach związanych $\mathrm{z}$ dwu i wielojęzycznym charakterem miejsc, w których znaki się znajdują. Funkcja mitologiczno-folklorystyczna jest ściśle związana z nazewnictwem miejsc, które może wywodzić się z tradycyjnych opowieści, sag, mitów, nierozerwalnie związanych $\mathrm{z}$ daną tradycją kulturową. 
Dzięki temu mieszkańcy danego terytorium mogą odczuwać większą przynależność do danego miejsca, poczuć wyraźny z nim związek. Pejzaż językowy pełni funkcję mitologiczno-folklorystyczną, ponieważ pozwala także zachować więź z tradycją i historią. Jako przykład Hicks (2002) wskazywał np. pierwotne ludy Ameryki lub Australii, dla których tradycyjne nazwy są często jedyną pozostałością po ich skolonizowanej i podbitej kulturze. Zastąpienie nazw w języku danej kultury inną nazwą, pozbawia daną kulturę istotnych elementów tradycji, co może być równoznaczne $\mathrm{z}$ atakiem na daną kulturę. W kontekście polskich miast i ich pejzażu językowego, można założyć, że funkcja mitologiczno-folklorystyczna częściowo przybiera inny charakter, głównie z powodu innej historii, tradycji, kultury oraz sytuacji językowej. Niniejszy artykuł jest poniekąd próbą rozszerzenia pojęcia funkcji mitologiczno-folklorystycznej Hicks'a i w związku z tym wskazaniem, że pejzaż językowy może przyczynić się do umocnienia i szerzenia wiedzy o dziedzictwie kulturowym.

\subsection{Funkcja nazewnictwa}

Na pejzaż językowy składają się m.in. tablice $\mathrm{z}$ nazwami ulic czy tablice informacyjne. Poza wspomnianymi już aspektami mitologiczno-folklorystycznymi, warto wskazać na bardziej szczegółowe funkcje, jaki pełni samo nazewnictwo oraz związane z nim teksty umieszczone na tablicach.

Nazewnictwo miejskie wytwarza tzw. przestrzeń onimiczną (patrz Siwiec 2006), którą tworzą nazwy wszystkich elementów przestrzeni, które widzą i doświadczają użytkownicy przestrzeni miejskiej. Należy zaznaczyć, że nazewnictwo bierze udział w kreowaniu przestrzeni poprzez „nazywanie i oznaczania, identyfikację i wyróżnianie" (Siwiec 2006: 116).

W analizie nazewnictwa ulic ważne jest nie tylko spojrzenie językoznawcze, ale także zwrócenie uwagi na aspekty historyczne i społeczne (Chojnacki 2008). Wydarzenia historyczne czy polityczne miały dość istotny wpływ także na kształtowanie się przestrzeni miejskiej. Nazewnictwo ulegało procesom przemiany, tak jak zmieniała się sytuacja polityczno-gospodarczo-społeczna danego miasta czy kraju. Za przykład może posłużyć nazewnictwo powstałe podczas rozbiorów, tj. pojawienie się nazw niemieckich, czy nazewnictwo w czasach PRL-u, nawiązujące do ówczesnej sytuacji politycznej (Chojnacki 2008 za Gąsiorowski 1984).

Nazewnictwo ulic kształtuje się także pod wpływem zmian organizacyjnych miast. I tak Chojnacki podkreśla (2008: 523), iż zmieniająca się struktura miast, powstawanie coraz to nowszych „,ciągów komunikacyjnych” oraz stała obecność ludzi „uruchamia [...] system nazewniczy, określający położenie powstałych obiektów (tj. ulic, placów, mostów) oraz eksponujący inne określone interesem 
różnych dziedzin rzemieślniczych i handlowych informacje, dotyczące tychże obiektów". Warto byłoby więc przedstawić, skąd biorą się niektóre z nazw ulic, sięgając do przykładów z Poznania (Chojnacki 2008):

- ulica Wrocławska czy ulica Wroniecka - ich nazwy pochodzą od innych dużych miast; od nieistniejących już bram Wronieckiej i Wrocławskiej wiodły drogi w kierunku Wronek i Wrocławia;

- ulica Szewska - jej nazwa nawiązuje do grupy rzemieślniczej, działającej przy owej ulicy;

- ulica Dominikańska, Klasztorna, Kościelna, pl. Bernardyński - nazwy tych ulic i placu nawiązują do „miejsc kultu religijnego”, które przy tych ulicach/placu były usytuowane;

- ulice Grobla, Ostrówek, Wodna - ich nazwy wskazują dawny „charakter topograficzny ulic i placów";

- ulice Berdychowo, Półwiejska, Wierzbięcice - nazwy tych ulic związane są z wsiami czy osadami, które z czasem zostały włączone do miasta Poznania.

Jedną $\mathrm{z}$ dużych grup nazw, które są obecne w przestrzeni miasta Poznania, są nazwy odosobowe. Zaczęły powstawać od końca XIX wieku i są tworzone aż do dziś. Od momentu ich pojawienia się miały one często charakter polityczny i ideologiczny. I tak w okresie zaborów, główna ulica reprezentacyjna Poznania nosiła nazwę króla pruskiego Wilhelmstrasse (obecnie Al. K. Marcinkowskiego). Chojnacki (2008) wskazuje również, że „na przełomie wieków XIX i XX wiele już ulic i placów Poznania nosiło nazwy utworzone od nazwisk pruskich marszałków i generałów, polityków i przedstawicieli administracji”. Przykładami ulic, które nawiązywały do treści niepodległościowych i patriotycznych były w okresie międzywojennym ul. Kazimierza Wielkiego, ul. Umińskiego, ul. Belwederska, al. Niepodległości, pl. Wolności. Dla utrwalenia i przypomnienia znaczenia urzędów Polski przedrozbiorowej, nadawano ulicom takie nazwy, jak Kanclerska, Marszałkowska, Postolińska czy Podkomorska. Jednakże po drugiej wojnie światowej, wraz ze zmianą ustroju politycznego, zaczęły pojawiać się nazwy do ówczesnego ustroju nawiązujące, np. ul. Armii Czerwonej (dzisiaj św. Marcin), ul. Dzierżyńskiego (dzisiaj ul. Półwiejska).

Obecnie ulice miasta Poznania lub raczej ich nazwy zmieniły swój charakter i przede wszystkim funkcję. Chojnacki (2008: 524) wskazuje, że „nazwy [...] już 'nie krzyczą', 'nie agitują', nie zawierają żadnych innych informacji poza przyporządkowaniem ich określonym miejscom czy ciągom komunikacyjnym. Nazwy ulic i placów pełnią już tylko funkcję porządkującą, adresową". Warto również zaznaczyć, że wiele nazw zawiera treści już nieaktualne np. ul Szewska, na której nie ma już szewców. Co więcej, Chojnacki (2008) podkreśla, że na skutek rozwoju i rozbudowy miast i potrzeby nadawania nazw coraz to nowszym ulicom, placom itd., nowopowstałe nazwy nie mają ,żadnego związku semantycznego z nazwanymi obiektami”, np. ulica Giżycka. 
W niniejszym opracowaniu spróbujemy wykazać, jak wykorzystać nazewnictwo w poznawaniu i szerzeniu wiedzy o dziedzictwie kulturowym, pomimo zmieniającej się funkcji nazewnictwa. Analiza tablic informacyjnych przedstawionych w badaniu, mimo iż bezpośrednio odwołuje się do wyżej wspomnianych nazw i ich etymologii, jest przede wszystkim próbą wskazania znaczenia pejzażu językowego (tym samym analizowanych tablic $\mathrm{z}$ nazwami) w podtrzymywaniu i szerzeniu wiedzy na temat dziedzictwa kulturowego.

\section{Ekoturystyka, czyli poznawanie dziedzictwa kulturowego poprzez „odczytywanie” przestrzeni miejskiej}

Dziedzictwo kulturowe jest nieodłącznym elementem przestrzeni miejskiej. Człowiek, użytkownik przestrzeni jest ogniwem łączącym oba pojęcia. Zarówno dziedzictwo jak i przestrzeń zostały wytworzone przez człowieka, a przestrzeń jest nośnikiem dziedzictwa, to w niej dziedzictwo jest ukryte, zachowane.

Dziedzictwo kulturowe w tradycyjnym ujęciu, podawanym przez UNESCO, dzieli się na materiale i niematerialne. W kontekście przestrzeni miejskiej wydawać by się mogło, że najbardziej zauważalne i być może dlatego najbardziej istotne, jest dziedzictwo materialne, czyli to które każdy z mieszkańców może zauważyć, dotknąć i doświadczyć. Według UNESCO, za dziedzictwo materialne można uznać zabytki, budynki, jak również miejsca o historycznym, estetycznym, archeologicznym, naukowym, etnologicznym i antropologicznym znaczeniu. Dla rozróżnienia dziedzictwo niematerialne odnosi się do zwyczajów, przekazów ustnych, umiejętności związanych z rzemiosłem tradycyjnym, wiedzy, języka, który jest nośnikiem dziedzictwa, sztuk widowiskowych, rytuałów czy obrzędów.

Poznawanie dziedzictwa kulturowego danego miejsca czy regionu zazwyczaj odbywa się w sposób konwencjonalny, tj. poprzez sięganie do przewodników książkowych, korzystanie z usług profesjonalnych przewodników, którzy przekazują informacje o historii danych obiektów, opowiadają o wydarzeniach, jakie zaistniały. O klasycznych formach turystyki wspominają m.in. Kaczmarek i Kaczmarek (2009) zaliczając do nich zwiedzanie zabytków, miejsc o wartości historycznej, udział $\mathrm{w}$ wydarzeniach kulturalnych i religijnych. Jest to niewątpliwie związane z celem, jaki obierają sobie turyści przybywający do miasta, tj. albo chęci doświadczenia kultury materialnej albo niematerialnej, co naturalnie nawiązuje do form dziedzictwa kulturowego. Turyści mogą więc skupić się bardziej na przeszłości, czyli na zabytkach czy spuściźnie (dziedzictwie) albo na teraźniejszości (obecnych wydarzeniach) lub współczesnych wytworach materialnych (zob. Kaczmarek i Kaczmarek 2009: 17).

Tymczasem, jak spróbuję przedstawić w niniejszym artykule, istnieją również inne, równie ciekawe, a może nawet bardziej fascynujący sposoby poznawania 
dziedzictwa. Pozwalają one na samodzielne odkrywanie historii, poznawanie wydarzeń i ludzi. Owe nowe sposoby wykorzystują pejzaż językowy miasta. Pejzaż językowy, jak wyżej zdefiniowany, odwołuje się do języka znajdującego się na różnego rodzaju znakach umieszczonych $\mathrm{w}$ przestrzeni miejskiej. Do treści umieszczonej na znakach, w tym przypadku na tablicach informacyjnych, właśnie należy się odnieść przy odkrywaniu dziedzictwa kulturowego.

Połączenie badań nad dziedzictwem kulturowym z zagadnieniem pejzażu językowego, nawiązuje również do coraz częściej pojawiającego się literaturze pojęcia ekoturystyki miejskiej. Jak wspomniano powyżej, poznawanie środowiska miejskiego, przestrzeni może następować poprzez wykorzystywanie tablic informacyjnych umieszczonych w przestrzeni miejskiej. Należy się jednak zastanowić, kto, jaki użytkownik przestrzeni będzie skłonny podążać za nową formą turystyki. Kaczmarek i Kaczmarek (2009: 9, za Rewers 2008) zaproponowali trzy typy turysty miejskiego: pielgrzyma, spacerowicza i obserwatora. I tak, pielgrzym, merytorycznie przygotowany, konfrontuje wcześniej nabytą wiedzę z rzeczywistością, posiada zasób teoretycznej wiedzy o odwiedzanym miejscu i chce ją sprawdzić. Spacerowicz z kolei poddaje się wydarzeniom odbywającym się w przestrzeni miejskiej. Istotnym elementem, który pozwala spacerowiczowi poznawać miasto są emocje, przeżywanie. Obserwator, w przeciwieństwie do spacerowicza, w sposób racjonalny bada otaczającą go rzeczywistość miejską. Nie poddaje się emocjom, nie daje się ponieść wydarzeniom obecnym w miejskiej rzeczywistość. Ekologia miasta, przestrzeni i tym samym ekoturystyka to naturalny sposób poznawania i absorbowania przestrzeni miejskiej. Analiza wybranych tablic informacyjnych umieszczonych w przestrzeni miejskiej Poznania ma na celu podkreślić znaczenie pejzażu językowego dla poznawania dziedzictwa kulturowego. Owa forma ekoturystyki lub turystyki miejskiej jest prawdopodobnie głównie przeznaczona dla turysty spacerowicza.

\section{Badanie - historia i dziedzictwo kulturowe ukryte w pejzażu językowym}

W celu udowodnienia przyjętego stwierdzenia, iż pejzaż językowy w przestrzeni miejskiej może pełnić istotną funkcję $\mathrm{w}$ rozpowszechnianiu i udostępnianiu wiedzy na temat historii i dziedzictwa kulturowego danego miasta, przeprowadzona została analiza tablic informacyjnych umieszczonych $\mathrm{w}$ centrum miasta Poznania.

Tablice informacyjne, które podległy analizie pojawiły się w ramach Systemu Informacji Miejskiej dla Poznania. Miały one różnorodne funkcje, takie jak identyfikacja adresu, informacja lokalizująca $\mathrm{w}$ przestrzeni miasta, informacja kierująca dla pieszych oraz kierowców, informacja komercyjna, informacja o wydarzeniach jednorazowych oraz informacja turystyczna (SIM ŹI). Analizowany 
w niniejszym opracowaniu materiał zaliczyć można do tablic zawierających informację turystyczną, tj. opisy zabytków, wydarzeń, miejsc, osób-patronów ulic.

W badaniu przeanalizowano 37 tablic. Wszystkie znajdują się w centrum miasta, głównie na elewacjach budynków, w łatwo dostępnym miejscu. Można wyodrębnić kilka grup tablic: tablice nawiązujące do budynku lub obiektu architektonicznego, związane z patronami ulic, nazwami placów, tablice z nazwami ulic - nawiązujące do miejsc, architektury i kierunków geograficznych, tablice nawiązujące do zawodów czy grup społecznych oraz tablice $\mathrm{z}$ nazwami ulic nawiązującymi do elementów architektonicznych. Przedstawiana analiza jest uporządkowana według powyższego podziału na grupy. Należy również zaznaczyć, że wszystkie podawane analizie informacje pochodzą tylko i wyłącznie z tablic informacyjnych. Nie sięgano do żadnych innych źródeł.

\section{Tablice nawiazujące do budynku lub obiektu architektonicznego}

(Most Teatralny, Teatr Wielki, Muzeum Narodowe, budynek administracyjnohandlowy, Muzeum Archeologiczne, Kościót Najśw. Krwi pana Jezusa, Kościót św. Antoniego i Klasztor Franciszkanów, Szkoła Baletowa, Dawny Hotel Saski)

Tablice te stanowią osobną grupę wśród analizowanych znaków. Jedną $\mathrm{z}$ cech wyróżniających je od pozostałych tablic, jest tekst, napisany w trzech językach, polskim, angielskim i niemieckim. Stanowią one tym samym typowy przykład znaku skierowanego nie tylko do polskojęzycznego użytkownika przestrzeni miejskiej, ale również do osób przyjeżdżających z zagranicy. Teksty umieszczone na tablicach na elewacjach wymienionych obiektów zawierają następujące informacje: w przypadku Mostu Teatralnego etymologię nazwy, na każdej tablicy pojawiają się daty wskazujące, kiedy obiekt został wzniesiony, krótką historię, opis architektoniczny, znaczenie i funkcje, jakie pełnił lub nadal pełni. Co więcej, często pojawiają się też informacje o postaciach/ludziach, którzy związani byli z danym budynkiem, nawiązując tym samym do mających miejsce wydarzeń historycznych.

\section{Tablice z nazwami ulic-patroni ulic}

Kolejną grupą znaków, są tablice z nazwami ulic, które wywodzą się od znanych osób, z tzw. patronami ulic. Wśród przeanalizowanych tablic było ich 10. Każda tablica oprócz nazwy ulicy, zawierała również podobiznę jej patrona oraz krótką notkę biograficzną. Istotne dla niniejszej analizy jest krótki tekst biograficzno-historyczny. Każdy zawierał daty urodzin i śmierci patrona oraz miejsce pochodzenia, pozwalając na natychmiastowe umiejscowienie danej osoby w czasie i przestrzeni. Istotną informacją było również wspomnienie zawodu czy zajęcia, jakim trudnił się patron, oraz jego związek z miastem Poznań. Na podstawie tablic z patronami ulic można uzyskać następujące 
informacje: jakie znane osoby były związane z Poznaniem, jaki miały udział w życiu społeczno-kulturalnym, jak zasłużyły się dla Poznania. I tak wśród patronów ulic można wyróżnić muzyków i kompozytorów (np. H. Wieniawski. I. Paderewski), pisarzy (A. Fredro), działaczy politycznych (K. Kantak), dyrygentów (F. Nowowiejski), lekarzy (K. Marcinkowski) oraz generałów (J. Dowbor-Muśnicki). Nie zawsze jednak patron ulicy związany był ściśle z Poznaniem, jak w przypadku ul. T. Kościuszki. W tym przypadku życiorys i działalność sprawiły, że jest istotną osobą w historii i dlatego jego imieniem opatrzono jedną z ulic. Inaczej jest również z ulicą Świętosławską, której nazwa według opisu na tablicy pochodzi od patrona fary biskupa św. Stanisława, która jest przy tej ulicy umiejscowiona. Tekst umieszczony na tablicach nie jest bardzo szczegółowy i rozwinięty, ale informacje w nim zawarte dostarczą osobie czytającej niezbędnych informacji o opisywanej osobie i tym samym ugruntują bądź poszerzą wiedzę na ich temat oraz o dziedzictwie kulturowym, które niektóre z tych osób stworzyły.

\section{Tablice z nazwami placów (plac Wolności, plac Kolegiacki, plac Bernardyński)}

$\mathrm{W}$ badanym materiale znalazły się trzy place. Tekst na tablicach zawiera opis miejsca, co znajdowało się w nim przed laty. Istotnym jest iż w owych opisach pojawiają się wzmianki o nazwach, o których nawet mieszkańcy Poznania nie zawsze słyszeli (pl. Wolności - niegdyś przedmieście Kundorf, później Musza Góra). Pojawienie się w opisie tego typu informacji zachęca do dalszych poszukiwań, zagłębiania się w historię miasta. Co więcej, opisy zawarte na tablicach wzmiankują również o budynkach, które się w danym miejscu znajdowały, jak na przykład nie istniejący już gotycki kościół św. Marii Magdaleny (od 1471 nosił tytuł kolegiaty) na placu Kolegiackim. Nazwa placu Bernardyńskiego, również pochodzi od budynku, tj. od klasztoru Franciszkanów umiejscowionego tuż obok. Jednakże nazwa Bernardyński nawiązuje do zakonu braci zamieszkujących klasztor, potocznie nazywanych bernardynami. Bez zagłębiania się w materiały źródłowe, bez sięgania do przewodnika, zwykły użytkownik przestrzeni nie zauważyłby, nie zastanawiałby się, czy dane miejsce mogło kiedykolwiek wyglądać inaczej. Tymczasem po raz kolejny, tablice umożliwiają poznanie, wprawdzie w niepełnej wersji, choćby fragmentu historii miasta i tym samym jego dziedzictwa.

Tablice z nazwami ulic - nawiąujące do miejsc, architektury, kierunków geograficznych

W badanym materiale pojawiła się grupa tablic, które zawierały nazwę ulicy, jednak jej pochodzenie trudno było sklasyfikować. Stąd pojawił się tytuł niniejszej sekcji tablice nawiazujące do miejsc, architektury, kierunków geograficznych. Niektóre z ulic, wzięły swoją nazwę od instytucji, które miały przy niej 
swoją siedzibę, jak np. ul. Sieroca, przy której od XVIII wieku znajdował się przytułek dla sierot i ubogich, bądź ulica Klasztorna, przy której znajdował się klasztor Benedyktynek. Poza wspomnieniem owych instytucji, w tekście umieszczonym na tablicach pojawia się również ich krótka historia, tj. od kiedy istniały i jak i czy zmieniło się ich położenie w mieście.

Kolejną podgrupę stanowią tablice $\mathrm{z}$ nazwami ulic nawiązującymi do istotnych dla miasta konstrukcji architektonicznych, jak również do kierunków geograficznych. Należą do nich między innymi ulica Wrocławska i Wroniecka. Informacje zawarte na tablicach thumaczą pochodzenie nazw, tj. istnienie w Poznaniu bram Wronieckiej (wychodzącej w kierunku północnym, w kierunku Wronek), oraz bramy Wrocławskiej, od której wiodła na południe droga w kierunku Wrocławia. Obie bramy już nie istnieją, pozostały jedynie ich ślady, które dokładnie wskazują ich lokalizację. Kolejną ulicą, która nawiązuje do konkretnego miejsca w Poznaniu, jest ulica Zielona. Jej nazwa nawiązuje do najstarszego w Poznaniu miejsca zielonego, dostępnego dla wszystkich. W przeciwieństwie jednak do wyżej wspomnianych bram, opisane miejsce istnieje do dnia dzisiejszego. Podobna sytuacja dotyczy ulicy Stawnej, której nazwa pochodzi od znajdującego się niegdyś przy niej stawu. Jej historia jest jednak o tyle ważna, że wzdłuż owego stawu biegły od średniowiecza mury miejskie. Kolejną ulicą, której nazwa pochodzi nie od elementów architektonicznych lecz uwarunkowań przyrodniczo-geograficznych, jest ulica Mokra. Jej nazwa nawiązuje do terenów bagiennych i mokradeł rozciągających się tuż za murami miejskimi. Ostatnią ulicą, której nazwa nawiązuję do jakiegoś miejsca w przestrzeni jest ulica Rynkowa. Jej nazwa pochodzi od drogi łączącej Stary Rynek z młynem wodnym.

Teksty na tablicach opisujące owe miejsca pozwalają skonfrontować uzyskane informacje z rzeczywistością, zobaczyć, np. w którym dokładnie miejscu dana brama stała. Jest to o tyle istotne, że tablice poniekąd zmuszają przechodnia do przeczytania zawartych na nich informacji. Bez nich dane miejsce może pozostać bez znaczenia. Po raz kolejny dziedzictwo kulturowe (architektura miasta) są uwiecznione w języku, tekście, pejzażu językowym.

Tablice nawiazujące do zawodów (ul. Kramarska, ul. Masztalarska, ul. Szewska, ul. Garbary)

Wśród analizowanych tablic z nazwami ulic znalazły się trzy nawiązujące do zawodów. Dla współczesnych mieszkańców Poznania nazwy tych ulic nie wiążą się $\mathrm{w}$ żaden sposób $\mathrm{z}$ danym miejscem. Tymczasem $\mathrm{z}$ umieszczonych na tablicach opisów wynika, iż na ulicy Kramarskiej stały niegdyś jatki i kramy, przy ul. Masztalerskiej mieściła się w okresie rozbiorów zajezdnia taboru miejskiego i to od masztalerzy, którzy opiekowali się końmi, wzięła się nazwa ulicy. Z kolei przy ulicy Szewskiej znajdowało się niegdyś wiele warsztatów szewskich. Inna ulica, 
ulica Garbary, nawiązuje w swej nazwie do nieistniejącej już oddzielenie osady zamieszkałej przez garbarzy. Poza informacjami nawiązującymi ściśle do nazwy ulicy, pojawiają się również krótkie wzmianki historyczne wskazując od kiedy ulica istnieje oraz ewentualnie, co się przy niej obecnie znajduje. Pojawianie się krótkich opisów tłumaczących pochodzenie nazw ulic pozwala na wyobrażenie sobie, co się niegdyś przy niej znajdowało, jacy ludzie na niej przebywali, czym się zajmowali. Są również przypomnieniem o nieistniejących już profesjach.

\section{Tablice nawiazujace do grup społecznych (ul. Żydowska)}

Nazwa jednej z ulic, umieszczonej na analizowanych tablicach, nawiązuje w swym opisie do grup społecznych, które zamieszkiwały daną część miasta lub wieś w późniejszym okresie wcieloną o obręb miasta, obecnie już nieistniejącą. Jest to ulica Żydowska. Według zamieszczonego na tablicy opisu ta część miasta, w której znajduje się ulica, była niegdyś zamieszkana przez ludność żydowską. Informacje zawarte na tablicach to nie tylko czysto historyczne fakty o zaistniałych wydarzeniach to również informacja o przekroju społecznym danego miasta.

\section{Tablice z nazwami ulic nawiazującymi do elementów architektonicznych (ul. Gotębia, ul. Kozia)}

Warte zauważenia wydają się również tablice z nazwami ulic, które nawiązują do elementów w architekturze, na które obecnie niewiele osób zwraca uwagę. Opis umieszczony na tablicy i wyjaśniający pochodzenie nazwy ulicy, jest bodźcem do przyjrzeniu się otaczającej przestrzeni i architekturze. W przypadku ulicy Gołębiej, poza opisem tego, co znajdowało niegdyś przy owej uliczce, widnieje również wyjaśnienie nazwy (właściwie przypuszczenie), tj. nazwa prawdopodobnie nawiązuje do godła znajdującego się na jednym $\mathrm{z}$ domów albo od dużej liczby gołębi przylatujących i siedzących w pobliżu. Podobnie tłumaczy się nazwę ulicy Koziej, tj. mówi się, że pochodzi ona od godła umieszczonego na kamienicy lub gospodzie. Oczywiście każda tablica z nazwami omawianych ulic zawiera również informacje dotyczące mieszczących się niegdyś przy nich budynków lub np. murów miejskich (ul. Gołębia).

\section{Wnioski}

Analizowane w badaniu tablice z nazwami ulic, z opisem budynków, czy miejsc, okazały się bogatym źródłem informacji na temat miasta. Należy podkreślić, że wszystkie informacje przedstawione $\mathrm{w}$ analizie czerpane były tylko i wyłącznie $\mathrm{z}$ tablic. Krótkie teksty umieszczone na tablicach, tworzą wspólnie pejzaż językowy, który w sposób przystępny dla przeciętnego użytkownika przestrzeni 
opisuje dziedzictwo kulturowe danego miasta i tym samym danej społeczności. Jeśli spojrzeć na wszystkie przeanalizowane ulice i pogrupować je tak jak to zostało zrobione w niniejszym artykule, można pokusić się o próbę odtworzenia niektórych wydarzeń historycznych, przekroju społecznego (dawne zawody), budynków, elementów architektonicznych, znaczenia niektórych instytucji w Poznaniu. W kontekście turystyki miejskiej czy ekoturystyki wyraźnie zaznacza się istotna rola przestrzeni jako źródła informacji o rzeczywistości, bez konieczności sięgania do rozległych, obszernych źródeł, takich jak przewodniki czy chociażby encyklopedie. Uważna obserwacja, a także chęć udziału w pewnego rodzaju grze czy w dialogu z przestrzenią pozwala dotrzeć do niezwykłych historii o pozornie zwykłych lecz z czasem już zapomnianych miejscach i ludziach.

Poznawanie i wykorzystywanie pejzażu językowego pozwala odbierać i doświadczać przestrzeń przede wszystkim turyście-spacerowiczowi. Wymaga wprawdzie od niego czasu i wysiłku, ale może się okazać bardzo inspirujące.

Należałoby również zaznaczyć na koniec, że przestrzeń dostarcza informacji w kontekście. Tablice zdjęte z fasad budynków tracą swoje znaczenie. Dopiero umieszczenie ich w przestrzeni miejskiej nadaje sens treściom, które niosą. Co więcej, użytkownik przestrzeni może skonfrontować otrzymaną informację z rzeczywistością i jest tym samym poniekąd zmuszony do uruchomienia własnej wyobraźni, w celu odtworzenia dawnego obrazu społeczno-kulturowego danego miejsca.

\section{Literatura}

Buczkowska, K. i A.M. von Rohrscheidt. 2009. (red.). Wspótczesne formy turystyki kulturowej. Poznań: Akademia Wychowania Fizycznego im. E. Piaseckiego w Poznaniu.

Chojnacki, J. 2008. „Nazwy ciągów i obiektów komunikacyjnych (ulic, alei, placów, mostów itp.)”. W zbiorze: Zagórski, Z. (red.). 427-540.

Gąsiorowski, A. 1984. „Nazwy poznańskich ulic. Przemiany i trwanie: wieki XIV-XX”. Kronika Miasta Poznania 3-4. 23-64.

Hicks, D. 2002. „Scotland's linguistic landscape: the lack of policy and planning with Scotland's place-names and signage". Paper presented at the World Congress on Language Policies, Barcelona April 2002. <www.linguapax.org/congres/taller/taller2/Hicks.html>, 2006.

Kaczmarek, J. i S. Kaczmarek. 2009. „Turystyka kulturowa - człowiek w miejskiej przestrzeni wymiany”. W zbiorze: Buczkowska, K. i A. M. von Rohrscheidt. (red.). 7-35.

Landry, R. i R.Y. Bourhis. 1997. „Linguistic landscape and ethnolingustic vitality: an empirical study". Journal of Language and Social Psychology 16 (1). 23-49.

Rewers, E. 2008. „Od miejskiego genus loci do miejskich oligoptionów”. Konteksty 3-4. 282-283.

Siwiec, A. 2006. „Przestrzeń miejska jako przestrzeń onimiczna (uwarunkowania lingwistycznokulturowe)”. W zbiorze: Święcicka, M. (red.). 115-128. 
Święcicka, M. (red.). 2006. Przestrzeń zróżnicowana językowo, kulturowo i społecznie. Miasto. Bydgoszcz: Wydawnictwo Uniwersytetu Kazimierza Wielkiego.

Zagórski, Z. 2008. (red.). Nazewnictwo geograficzne Poznania. Poznań: Wydawnictwo Naukowe UAM.

UNESCO <http://www.unesco.pl/kultura/dziedzictwo-kulturowe/dziedzictwo-niematerialne>.

\section{Załącznik - przykładowe teksty $\mathrm{z}$ tablic informacyjnych}

\section{Tablice nawiazujace do budynku lub obiektu budowlanego}

Teatr Wielki (Grand Theatre, originally the New Municipalk Theatre; Grossem Theater, ursprunglich neues Stadttheater)

Opis: Zbudowany w latach 1908-10 wg projektu monachijskiego architekta, Maxa Littmana, jako Teatr Miejski. Neoklasycystyczny. Po odzyskaniu niepodległości scena operowa pod obecną nazwą (1950-79 jako Opera Poznańska im. Stanisława Moniuszki). Na szczycie gmachu charakterystyczna rzeźba Pegaza.

Tekst w j. angielskim: GRAND THEATRE, originally the new MUNICIPAL THEATRE

Built in 1908-1910 as a Municipal Theatre in neo-classicist style to a design by a Munich architect Max Littman. Since the regaining of independence by Poland, it has been used by the opera under the present name (in 1950-1979 known as the Stanisław Moniuszko Poznań Opera). The top of the building features the characteristic sculpture of Pegasus.

Tekst w języku niemieckim: GROSSES THEATRE, ursprünglich neues STADTTHEATRE

Erbaut in deb Jahren 1908-10 nach dem Entwurf des Münchner Architekten Max Littman als Stadttheater. Neuklassizistisch. Nach der Unabhängigkeitwiedergewinnung die Opernbühne inter dem heutigen Namen (1950-79 als Poznaner Opernhaus namens Stanisław Moniuszko). Auf dem Giebel des Gabäudes charakteristische Skulptur des Pegasus.

\section{Tablice z nazwami ulic-patroni ulic}

Ulica A. Fredry

Opis: Aleksander Fredro (1793-1876) urodził się w Surochowie k. Jarosławia. W 1822 r. uzyskał tytuł hrabiowski. Był najwybitniejszym polskim komediopisarzem, autorem chętnie oglądanych komedii i fars, przede wszystkim barwnie przedstawiających życie ówczesnej szlachty. Pisał także wiersze. Zmarł we Lwowie. Teatry poznańskie często wystawiały jego sztuki.

Tablice z nazwami placów (plac Wolności, plac Kolegiacki, plac Bernardyński) Plac Kolegiacki

Opis: Dawniej stał tu gotycki kościół św. Marii Magdaleny, który w 1471 r. uzyskał tytuł kolegiaty. Była to najokazalsza świątynia dawnego Poznania. Zniszczenia w XVIII w. i brak zgody władz pruskich na odbudowę spowodowały rozebranie murów kościoła w 1799 r. $\mathrm{Na}$ jego miejscu powstał plac, który od 1803 r. nazywano Nowym Rynkiem, a w 1935 r. otrzymał obecną nazwę. 
Tablice z nazwami ulic - nawiąujące do miejsc, architektury, kierunków geograficznych

ul. Wroniecka

Opis: Ulica powstała w XIII w. podczas wytyczania miasta średniowiecznego. Wiodła od Starego Rynku do bramy Wronieckiej, przez którą prowadził wylot z Poznania w kierunku północnym. Nazwa pochodzi od miasta Wronki, ongiś własności królewskiej, które przed rozbiorami odgrywało większą rolę niż obecnie. Fundamenty bramy Wronieckiej niedawno odsłonili archeolodzy.

Tablice nawiazujące do zawodów (ul. Kramarska, ul. Masztalarska, ul. Szewska, ul. Garbary)

ul. Masztalarska

Opis: Ulica ta powstała jeszcze w okresie przedrozbiorowym. Przedłużono ją w XIX w., a obecny kształt otrzymała krótko przed I wojną światową. W okresie rozbiorów miała tu siedzibę zajezdnia taboru miejskiego, a od zatrudnionych w niej masztalerzy (osób opiekujących się końmi) została urobiona nazwa ulicy. W 1877 r. wybudowano tutaj strażnicę straży ogniowej.

\section{Tablice nawiąujące do grup spotecznych (ul. Żydowska)}

ul. Żydowska

Opis: Ulica powstała w XIII w. podczas wytyczania lewobrzeżnego Poznania. Od XV w. była ona zwana Sukienniczą lub Żydowską. W tym rejonie Starego Miasta znajdowała się dzielnica zamieszkała w średniowieczu przez ludność żydowską. Poszerzenie na części długości ulicy pochodzi z okresu, gdy po wielkim pożarze miasta w 1803 r. została ona wytyczona na nowo.

Tablice z nazwami ulic nawiąującymi do elementów architektonicznych (ul. Gotębia, ul. Kozia)

ul. Gołębia

Opis: Uliczka ta istnieje od średniowiecza i pierwotnie przebiegała w sąsiedztwie murów miejskich. W XVII-XVIII w. powstał przy niej kościół jezuitów - obecna fara. Nazwę swą ulica otrzymała jeszcze przed rozbiorami. Może ona wywodzić się od godła umieszczonego na jednym z domów, nazwy stojącej tu karczmy, czy licznych gołębi, do dziś gromadzących się przy farze. 
